
ДАМУ ҮРДІСТЕРІ

\title{
TRENDS IN THE DEVELOPMENT OF CITRUS GROWING IN THE REPUBLIC OF KAZAKHSTAN
}

\author{
Г.Ш. КАЛИАКПАРОВА* \\ доктор Ph.D \\ Е.Е. ГРИДНЕВА \\ к.э.Н., доцент \\ академия «Кайнар», Алматы, Казахстан \\ *электронная почта автора:GK_2003@rambler.ru \\ Г.Ш. КАЛИАКПАРОВА* \\ Ph.D докторы \\ Е.Е. ГРИДНЕВА \\ э.ศ.к., доцент \\ «Қайнар» академиясы, Алматы, Қазақстан \\ *автордың электрондық поштасы: GK_2003@rambler.ru \\ G.SH. KALIAKPAROVA* \\ Ph.D \\ Y.E. GRIDNEVA \\ C.E.Sc., Associate Professor \\ "Kainar" Academy, Almaty, Kazakhstan \\ *corresponding author e-mail: GK_2003@rambler.ru
}

Аннотация. Цель - обозначить возможности и перспективы производства цитрусовых в Республике Казахстан, экономическую целесообразность выращивания цитрусовых культур в стране по сравнению с импортной продукцией, а также преимущества для предпринимателей при их возделывании, хранении, доставке и реализации. Методы исследования статистический, аналитический, абстрактно-логический. Результаты - показаны области использования цитрусовых плодов в различных отраслях: сельское хозяйство, пищевая промышленность, медицина и др. Представлен зарубежный опыт. Проанализированы статистические данные по ценам, импорту цитрусовых на территорию республики. Обобщены факторы, сдерживающие их получение в больших количествах: усиление конкуренции со стороны государств ближнего и дальнего зарубежья; слабо развитые инфраструктура по переработке этих фруктов, транспортная логистика, сбыт готового ассортимента продуктов, недостаточная заинтересованность инвесторов. Выводы - необходимы действенная государственная поддержка отрасли, обновление материально-технической базы селекционных и семеноводческих хозяйствующих субъектов, применение новейших технологий, цифровизации для повышения урожайности, производства экологически чистой продукции, создание условий для продвижения казахстанских цитрусовых продук-тов на экспорт, организация совместных торговых миссий и согласованность между производителями стран-участниц Евразийского экономического союза и другими зарубежными партнерами. Медицина отводит цитрусовым культурам исключительно важное место в рациональном питании человека, поскольку витамины и минеральные соли, содержащиеся в них, являются такими же важными элементами питания, как белки, жиры и углеводы. За последнее столетие в мировом садоводстве цитрусовые плантации заняли первое место, оставив далеко позади яблоневые, грушевые, сливовые и вишневые сады.

Аңдатпа. Мақсаты - Қазақстан Республикасында цитрус жемістерін өндірудің мүмкіндіктері мен перспективаларын, импорттық өніммен салыстырғанда елде цитрус дақылдарын өсірудің экономикалық орындылығын, сондай-ақ оларды өсіру, сақтау, жеткізу және өткізу 


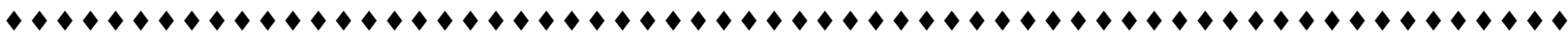
кезінде кәсіпкерлер үшін артықшылықтарды белгілеу. Зертmеу әдістері - статистикалық, аналитикалық, дерексіз-логикалық. Нәтижелері - цитрус жемістерін әртүрлі салаларда пайдалану салалары көрсетілген: ауыл шаруашылығы, тағам өнеркәсібі, медицина және т.б. шетелдік тәжірибе ұсынылған. Республика аумағындағы цитрус жемістерінің бағасы, импорты бойынша статистикалық деректер талданған. Олардың көп мөлшерде алынуын тежейтін факторлар жинақталған: жақын және алыс шетел мемлекеттері тарапынан бәсекелестіктің күшеюі; осы жемістерді қайта өңдеу бойынша инфрақұрылымның нашар дамуы, көлік логистикасы, өнімдердің дайын ассортиментін өткізу, инвесторлардың қызығушылығының жеткіліксіздігі. Қортындылар - саланы пәрменді мемлекеттік қолдау, селекциялық және тұқым шаруашылығы субъектілерінің материалдық-техникалық базасын жаңарту, жаңа технологияларды қолдану, өнімділікті арттыру, экологиялық таза өнім өндіру үшін цифрландыру, қазақстандық цитрус өнімдерін экспортқа шығару үшін жағдайлар жасау, бірлескен сауда миссияларын ұйымдастыру және Еуразиялық экономикалық одаққа қатысушы елдердің өндірушілері мен басқа да шетелдік әріптестер арасындағы келісімдер қажет. Медицина цитрус дақылдарына адамның ұтымды тамақтануында өте маңызды орын береді, өйткені олардың құрамындағы дәрумендер мен минералды тұздар ақуыздар, майлар және көмірсулар сияқты өте маңызды қоректік заттар болып табылады. Өткен ғасырда әлемдік бағбандықта цитрустық екпелер алма, алмұрт, өрік және шие бақтарын артта қалдырып, бірінші орынға ие болды.

Abstract. The goal - is to identify the possibilities and prospects of citrus production in the Republic of Kazakhstan, the economic feasibility of growing citrus crops in the country in compareson with imported products, as well as the benefits for entrepreneurs in their cultivation, storage, delivery and sale. Research methods - statistical, analytical, abstract-logical. Results - the areas of use of citrus fruits in various industries are shown: agriculture, food industry, medicine, etc. Foreign experience is presented. Statistical data on prices, import of citrus fruits to the terri-tory of the republic are analyzed. The factors that restrain obtaining their large quantities are summarized: increased competition from the CIS and foreign States; poorly developed infrastruc-ture for processing these fruits, transport logistics, marketing of the finished product range, insufficient investor interest. Conclusions - effective government support for the industry is nee-ded, as well as updating the material and technical base of breeding and seed-growing economic entities, application of the latest technologies, digitalization aimed to increase yields, production of environmentally friendly products, creating the necessary conditions for promoting Kazakhstani citrus products for export, organizing joint trade missions and consistency between manufacturers of the member countries of the Eurasian Economic Union and other foreign partners. Medicine rates citrus crops an extremely important place in the rational human diet, since vitamins and mineral salts contained in them are the same important nutrients as proteins, fats and carbohydrates. Over the past century, citrus plantations have taken the first place in world horticulture, leaving apple, pear, plum and cherry orchards far behind.

Ключевые слова: цитрусовые культуры, мини-фермы, материально-техническая база, селекционные и семеноводческие хозяйствующие субъекты, экспорт, импорт, товарооборот, импортозамещение, цифровизация, государственная поддержка.

Түйінді сөздер: цитрустық дақылдар, шағын фермалар, материалдық-техникалық база, селекциялық және тұқым өсіру шаруашылық субъектілері, экспорт, импорт, тауар айналымы, импортты алмастыру, цифрландыру, мемлекеттік қолдау.

Key words: citrus crops, mini-farms, material and technical base, breeding and seed-growing economic entities, export, import, trade, import substitution, digitalization, government support.

Введение. Слово «цитрус» в переводе с латинского языка означает «лимонное дерево». В республику из многих стран поступает достаточно большое количество цитрусовой продукции, при этом все равно имеются не удовлетворенные потребности населения в них. В открытых источниках данных о необходимости потребления цитрусовых на душу населения не имеется.
Согласно медицинским нормам, необходимое потребление на 1 человека фруктов (в том числе и цитрусовых) составляет 120 кг в год. По средним данным в Казахстане (на душу населения) в 2018г. потребление фруктов составило 77,9 кг, 2019г. - 77,4 кг [1]. Больше всего фруктов потребляют жители Мангистауской области - 101,8 кг на душу населения в среднем. На втором месте списка по потреблению 
фруктов расположился Алматы. Каждый житель южной столицы в среднем съел 99,4 кг фрруктов в 2020 году. Меньше всего фруктов потребляют в Шымкенте - лишь 61,3 килограмма. В 2020г. потребление фруктов на душу населения в домохозяйствах Казахстана составило на 0,5\% больше, чем в предыдущем 2019г. (2020г. 86,7 кг, 2019г. - 86,2 кг) [2].

Жители Казахстана на много меньше потребляют фрруковых соков. К сравнению на душу населения в США приходится в среднем - 70-80 л, в Германии - 43-45 л, в России - 16-18 литров. Тогда как в нашей республике апельсиновый и яблочный сок (предпочтительнее) потребляют в среднем 8,4 л в год, любители тропических соков 11-12 литров [3].

Одним из факторов решения продовольственной программы может стать импортозамещение, при этом совсем не предлагается отказаться от импортной продукции.

В республике выращивание цитрусовых культур пока очень ограничено, но вместе с тем существуют большие возможности их выращивания.

Материал и методы исследования. В настоящее время в Казахстане недостаточно исследована проблема возможности выращивания цитрусовых культур. Проводя исследования, необходимо учесть потребность населения в данном продукте, его полезные свойства, области применения в отраслях, территориальные и климатичес- кие особенности. В работе изучены импортные поставки цитрусовых в Казахстан.

Необходимым фактором и условием развития цитрусоводства является, прежде всего, государственная поддержка и содействие в становлении и развитии бизнеса: финансах, информационно-аналитической области, подготовке кадров и повышении квалификации в развитии данной области.

При анализе основных научных проблем, раскрытых в статье, использовались следующие методы:

- статистический - авторами были собраны и изучены материалы для проведения исследования и их систематизации, а также данные по импорту цитрусовых, исследованы цены за последние три года;

- аналитический - в Казахстане слабо изучены возможности выращивания цитрусовых, с этой целью был проведен анализ данных, полученных в результате исследования;

- абстрактно-логический - этот метод применялся авторами для разработки предложений и принятия решений, выявление проблемных вопросов и путей их решения.

Результаты и их обсуждение. Цитрусовые широко распространены в различных отраслях экономики, их используют как в декоративных целях, так и в лечении, ведь в них преобладает витамин С. Авторами проведен анализ возможности применения цитрусовых в основных отраслях экономики (таблица 1).

Таблица 1 - Область применения цитрусовых культур в отраслях

\begin{tabular}{|c|c|c|}
\hline $\begin{array}{c}\text { Область } \\
\text { применения }\end{array}$ & Эфрфрект & $\begin{array}{c}\text { Полезные } \\
\text { свойства }\end{array}$ \\
\hline $\begin{array}{l}\text { Пищевая } \\
\text { промышлен- } \\
\text { ность }\end{array}$ & \multirow[t]{2}{*}{$\begin{array}{l}\text { Применение в кондитерской промышленности (пектин). } \\
\text { Улучшение вкусовых качеств продукта (ароматизаторы, красители). }\end{array}$} & \multirow{6}{*}{$\begin{array}{l}\text { Витамины } \\
\text { (А,Е,С,Р, } \\
\text { каротин, } \\
\text { группа В), } \\
\text { фитонци- } \\
\text { дов, } \\
\text { калий, } \\
\text { флавоноид } \\
\text { (наринге- } \\
\text { нин) и др. }\end{array}$} \\
\hline Кулинария & & \\
\hline Медицина & \multirow{2}{*}{$\begin{array}{l}\text { Повышение иммунитета и антисептического действия на организм. } \\
\text { Борьба с целлюлитом и лишним весом. } \\
\text { Эфирные масла: апельсиновое, лимонное, грейпфрутовое (пар- } \\
\text { фюмерная промышленность, мыловарение). }\end{array}$} & \\
\hline Косметология & & \\
\hline $\begin{array}{l}\text { Сельское } \\
\text { хозяйство, } \\
\text { животно- } \\
\text { водство } \\
\text { (только для } \\
\text { КРС) }\end{array}$ & $\begin{array}{l}\text { Использование как удобрения в сельском хозяйстве. } \\
\text { Один из производных, составляющих корма для крупного рога- } \\
\text { того скота с низким показателем протеина. } \\
\text { Сокращение возможностей передачи вредных бактерий в виде } \\
\text { сальмонеллы и кишечной палочки через желудочно-кишечный } \\
\text { тракт коров. } \\
\text { Снижение уровня болезнетворных микроорганизмов в мясе } \\
\text { крупного рогатого скота. }\end{array}$ & \\
\hline $\begin{array}{l}\text { Дизайн } \\
\text { интерьера }\end{array}$ & Интерьер и экстерьер как декоративные растения. & \\
\hline
\end{tabular}


Цитрусовые культуры широко применяются в пищевой промышленности, в кондитерстве и кулинарии как самостоятельный продукт, соки, красители, ароматизаторы и т.д.

В медицине и косметологии широко применяются экстракты и масла цитрусовых фрруктов, особенно в средствах, предназначенных для борьбы с целлюлитом. В этом активно помогает аскорбиновая кислота, которая активизирует выработку коллагена, а значит, подтягивает кожу и делает ее более упругой. Также цитрусовые помогают активно бороться с лишним весом.

В производстве цитрусовые выжимки, которые состоят из кожицы, сердцевины и зерен, распределяют по-разному. Так, к примеру, побочные продукты от производства сока цитрусовых в дальнейшем реализуют как цедру. Кожицу цитрусовых широко применяют в пищевой промышленности и в животноводстве. В мировой практике цитрусовые широко используют для производства пектина. Влажные остатки после его производства тоже применяются в кормлении крупного рогатого скота. Цитрусовые выжимки являются продуктивным кормом для коров с низким уровнем протеина [4].

Исследования, проведенные американскими учеными Службы сельскохозяйственных исследований (ARS), показали, что подкормка крупного рогатого скота цитрусовой кожурой значительно снижает распространение патогенных бактерий (к примеру, кишечная палочка и сальмонелла) в желудочно-кишечном тракте. Что, в свою очередь, снижает уровень заражения мяса болезнетворными микроорганизмами, а также уменьшается необходимость применения антибиотиков, которые колют животным с целью их безопасности. Это приводит к росту спроса на отходы цитрусовых. Коровы с удовольствием потребляют кожуру цитрусовых [5].

Цитрусовые растения широко применяются в дизайне интерьеров и экстерьеров, также эти растения решают проблемы с очищением воздуха.

Целесообразно выращивать лимоны, мандарины и другие цитрусовые при санаторно-курортных учреждениях, в детских садах и школах, на предприятиях, при создании зимних садов.

В вышесказанном отметим следующее: при производстве и переработке цитрусовых всегда можно получить готовый продукт в виде самого цитрусового, цедры, пектина, корма для животных и т.д. Это безотходное производство. Отсюда возможности развития как пищевой промышленности, перерабатывающих комбинатов, кормления крупного рогатого скота, так и агропромышленного комплекса в целом, других отраслей экономики.

К цитрусовым относится большое количество фруктов - 32 рода, многие из них имеют гибридное происхождение. К примеру, гибрид грейпфрута и мандарина называют углифрут, смешение лайма с кумкватом - лаймкват. А смесь кумквата с мандарином носит название оранжекват. Таких примеров очень много.

К самым распространенным и всем известным видам цитрусовых относят лимоны, мандарины, апельсины и грейпфрут. Именно эти виды транспортируются и продаются повсеместно, они выращиваются во многих странах мира.

Рассмотрим товарооборот фруктов в нашей республике за последние три года. Импорт фрруктов за 10 месяцев 2018г. составил 340 млн долл. США, экспорт - 6,7 млн долл. США. За аналогичный период 2019г. импорт цитрусовых плодов - 278 млн долл. США, снижение - на сумму 62 млн долл. США по сравнению с предыдущим годом, экспорт вырос на 36,6 млн долл. США. По итогам первого полугодия 2020г. было ввезено на $30 \%$ больше апельсинов, чем за тот же период 2019г., что составило 4,2 тыс. тонн. Поставщиками были Египет, Турция и Россия, при этом Египет поставил в первом полугодии 2,3 тыс. т, Турция увеличила поставки на $2,7 \%$ $(862,8$ т). Из России также возросли объемы экспорта на 20,8\% (497,1 т).

В Казахстан импортируется большое количество лимонов, так в 2020г. импортировано 4,2 тыс. т, что на $30 \%$ выше, чем в 2019 году. Наибольшее количество поставок лимонов осуществили: Китай - 2 тыс. т (на 34,9 \%), Узбекистан - 1,5 тыс. т (меньше на 45\%), Турция- 0,5 тыс. т (меньше на 21\%) [6].

Также лидерство по импорту держат и мандарины. Республика является стабильным покупателем для стран-производителей, первенство среди которых держат Китай и Пакистан (93,2\%), также поставщиками являются Южная Африка, Аргентина, Грузия и другие страны. Так, по данным Комитета государственных доходов Министерства финансов Республики Казахстан за первые десять месяцев 2019г. в страну было завезено в среднем 22 тыс. т мандаринов. Для сравнения, в 2018г. было экспортировано в нашу страну более 60 тыс.т: 36,2 тыс. т - Китай и 27,7 тыс. т - Пакистан. 
Помимо этого, в Казахстан были ввезены мандарины из Турции - 1,7 тыс. т, Ирана - 182 т, Грузии - 138 т, Марокко - 94 тонны [7].

За первое полугодие 2020г. импорт мандаринов составил 19,9 тыс. т, из них
Пакистан - 16,3 тыс. т, Китай - 2 тыс. т, Турция - 1,1 тыс. тонн [см. 6].

В пандемию коронавируса COVID-19 в апреле 2020г. наибольший месячный рост цен показали лимоны - сразу на 47,9\% (ранее за март эти цитрусовые уже подорожали почти на 3\%) (таблица 2).

Таблица 2 - Розничные цены на цитрусовые, тг за кг

\begin{tabular}{|l|c|c|c|c|c|}
\hline \multicolumn{1}{|c|}{ Фрукты } & $2020 / 04$ & $2020 / 03$ & $2019 / 04$ & Рост за месяц, \% & Рост за год, \% \\
\hline Лимоны & 1172 & 793 & 768 & 47,9 & 52,7 \\
\hline Апельсины & 651 & 636 & 533 & 2,5 & 22,2 \\
\hline \multicolumn{7}{|l}{ Примечание: [8] }
\end{tabular}

Цена цитрусовых на август 2021г. колеблется от 200-350 тг за штуку или от 1500-2000 тг за килограмм в зависимости от региона.

Небольшой производственный опыт выращивания цитрусовых культур в Казахстане показал ограниченность: их выращивают садоводы-любители в комнатных условиях, мини-хозяйствах или отдельные фрермеры в г. Шымкент, г. Кентау, Толебийском и Сарыагашском районах ЮКО. На общей площади всего в 20 га происходит выращивание данных культур в ЮКО, что ничтожно мало для этого региона. Так как именно здесь климатические условия подходят для освоения производства цитрусовых культур [9].

Следует отметить еще несколько районов - Туркестанская, Алматинская области, где выращивают на мини-фермах цитрусовые культуры. Число желающих поэкспериментировать с экзотикой в регионе растет, фермеры намерены объединиться. В Туркестанской области планируют создать ассоциацию лимоноводов.

Также возможно развивать бизнес в этом направлении с учетом их биологических особенностей в специальных сооружениях, таких как освещение, температура, поливочный режим. Примером может служить фермер в Атырауской области, адаптировавший лимонарии на солончаке в 20 теплицах, где растут 2000 саженцев, при этом получая урожай 1,5 т ежегодно. Фермер объясняет хороший урожай правильно выбранными подкормками и поливом, а также соблюдением температуры в теплицах.

В СКО (даже в 30 градусные морозы) круглый год в подземном тепличном комплексе на $1000 \mathrm{~m}^{2}$ на глубине 3 метров от поверхности земли выращивают тропические растения - лимоны, мандарины, грейпфруты, бананы, кофе, оливки и др. Всего более 400 наименований.

Вместе с тем, аграрии приобретают саженцы из Узбекистана, Грузии, России, Украины, Европы, Таиланда, Турции, Китая и др. стран через интернет-фрорумы, реже у отечественных аграриев. Борьбу с вредителями в основном ведут без помощи химии, запускают других насекомых хищников - энтомофагов. Удобрения используют только натуральные. Следовательно, продукт является экологически чистым. Как отмечают фермеры, никаких сверх особых затрат и хлопот лимоны не требуют, топить теплицы начинают, когда на улице минус семь градусов. При этом расходы угля минимальные. Экономически лимонный бизнес очень выгоден, но прибыль приходит только через шесть-семь лет после того, как дерево вырастет.

Возможности выращивания цитрусовых в Казахстане огромные. Разведение цитрусовых позволит создать новые рабочие места не только для квалифицированных, но и низкоквалифицированных кадров из числа активного населения. За счет разведения цитрусовых, имеющих высокую урожайность, можно повысить экономические показатели садоводства и других отраслей экономики, как было сказано выше. Необходимо дополнительное научное изучение возможностей выращивания, переработки и технологий сохранности цитрусовых. Здесь большую помощь может оказать применение новых технологий и цифровизации.

К первостепенным вопросам изучения рынка данного вида деятельности можно отнести рациональность использования уникальных природных условий, имеющийся пусть и небольшой опыт выращивания цитрусовых культур, анализ и изучение различных хозяйственно ценных видов и сортов. Надо также отметить, что процессы 
выведения и акклиматизации относительно длинные, как было сказано выше. Нужно еще изучать природу морозостойкости цитрусовых насаждений.

Выращивание в больших масштабах цитрусовых плодов и сдерживание их развития связано: с усилением конкуренции со стороны дальнего и ближнего зарубежья; слабо развитой инфраструктурой по переработке цитрусовых плодов и уровня логистики; не достаточно развитой технологической системой по выращиванию и складской инфраструктурой; сбытом продукции; слабой квалификацией фермеров, рисковой отраслью, слабой заинтересованность со стороны инвесторов.

Таким образом, хочется отметить, что в Казахстане имеются резервы импортозамещения на рынке цитрусовой продукции: интенсификация выращивания цитрусовых, создание специализированных предприятий, государственная поддержка.

\section{Заключение}

Предлагаем следующие пути создания благоприятных взаимовыгодных условий между участниками по выращиванию цитрусовых культур:

1. Поддержка государства в виде субсидий, выделение кредитных средств и широкий спектр других финансовых продуктов [10].

2. В области сотрудничества науки с вузами, НИИ: создание интегрированной информационной системы, нацеленной на взаимоотношения между вузами, НИИ и производством.

3. В области ресурсного обеспечения: поддержка выведения новых сортов и гибридов цитрусовых культур; обмен опытом в области применения лучших практик выращивания; оказание поддержки в обновлении материально-технической базы селекционных и семеноводческих хозяйствующих субъектов.

4. В области инноваций, цифровизации и трансферта технологий: увеличение урожайности, совершенствование технологий получения экологически чистой (органической) цитрусовой продукции.

5. В области экспортного потенциала: создание и продвижение казахстанского цитрусового продукта; организация совместных торговых миссий и налаживание согласованности в контрактах между производителями государств-членов ЕАЭС и зарубежными партнерами и т.д.
Список литературы

[1] Гриднева, Е.Е. Плодоовощная отрасль Южно-Казахстанского региона: состояние и перспективы / Е.Е. Гриднева, Г.Ш. Калиакпарова, Н.М. Калманова // Проблемы агрорынка. - 2020. - №3. - С. 180-186.

[2] Сколько тратят казахстанцы на фрукты и овощи [Электронный ресурс]. - 2021. URL: https: //ru.sputnik.kz/economy/20210402/ 16683147/ (дата обращения: 1.10.2021).

[3] Казахстан: рынок соков прямого отжима [Электронный ресурс]. - 2015. - URL: https: //ukrprod.dp.ua/2015/02/25/kazaxstan-rynok-sokov-pryamogo-otzhima.html (дата обращения: 1.10.2021).

[4] Плодово-ягодные выжимки (яблочный, виноградный, цитрусовый) в кормлении коров [Электронный ресурс]. - 2019. - URL: https://soft-agro.com/korovy/plodovo-yagodnyevyzhimki - yablochnyj - vinogradnyj - citrusovyjv-kormlenii-korov.html (дата обращения: 30.09.2021).

[5] Апельсины для коровы [Электронный pecypc]. - 2011. - URL: http://www.upakovano. ru/news/30077 (дата обращения: 12.10.2021).

[6] Комитет по статистике и доходов. Импорт - Экспорт цитрусовых [Электронный ресурс].-2020.-URL: https://kgd.gov.kz/ru/news/ archive?page=1(дата обращения: 13.10.2021).

[7] Что и откуда завозят в Казахстан в преддверии Нового года [Электронный ресурс]. - 2019. - URL:https://kursiv.kz/news/obschestvo/ 2019-12/ chto-i-otkuda-zavozyat-v-kazakhstan-v-preddverii-novogo-goda (дата обращения: 12.10.2021).

[8] Лимоны на вес золота: всего за месяц цена на эти полезные плоды цитрусовых выросла ещё на 48\% [Электронный ресурс]. 2020. - URL: https:// www.energyprom.kz/ru/a/ monitoring/ (дата обращения: 12.10.2021).

[9] Экзотические для Казахстана лимоны выращивают в районах ЮКО [Электронный pecypc]. - 2018. - URL: https://otyrar.kz/2018/01/ ekzoticheskie- dlya-kazaxstana-limony-vyrashhivayut-v-rajonax-yuko/ (дата обращения: 12.10.2021 г.)

[10] Тажибаева, Р.М. Государственная поддержка аграрного сектора Казахстана / P.М. Тажибаева // Проблемы агрорынка. 2021. - №1. - C. 44-49.

\section{References}

[1] Gridneva, Y.E., Kaliakparova G.Sh. \& Kalmanova N.M. (2020). Plodoovoshchnaya otrasl' Yuzhno-Kazakhstanskogo regiona: sostoyaniye i perspektivy [Fruit and vegetable industry of the South Kazakhstan region: state and prospects]. Problemy agrorynka - Problems of agrimarket, 3, 180-186. [in Russian]. 
[2] Skol'ko tratyat kazakhstantsy na frukty i ovoshchi [How much do Kazakhstanis spend on fruits and vegetables] (2021). Available at: https://ru.sputnik.kz/economy/20210402/166831 47/(date of access: 1.10.2021). [in Russian].

[3] Kazakhstan: rynok sokov pryamogo otzhima [Kazakhstan: the market of directly squeezed juices] (2015). Available at: https: // ukrprod.dp.ua/ 2015/ 02/ 25/kazaxstan-rynok-sokov-pryamogo-otzhima.html (date of access: 1.10.2021). [in Russian].

[4] Plodovo-yagodnyye vyzhimki (yablochnyy, vinogradnyy, tsitrusovyy) v kormlenii korov [Fruit and berry pomace (apple, grape, citrus) in cow feeding] (2019). Available at: https://softagro.com/ korovy/ plodovo-yagodnye-vyzhimkiyablochnyj- vinogradnyj- citrusovyj- v- kormleniikorov.html (date of access: 30.09.2021). [in Russian].

[5] Apel'siny dlya korovy [Oranges for the cow] (2011). Available at: http://www.upakovano.ru/news/30077. (date of access: 12.10.2021). [in Russian].

[6] Komitet po statistike i dokhodov. Import Eksport tsitrusovykh [Committee on Statistics and Income. Import - Export of citrus fruits] (2020). Available at: https://kgd.gov.kz/ru/news/ archive?page=1 (date of access: 13.10.2021). [in Russian].
[7] Chto i otkuda zavozyat v Kazakhstan v preddverii Novogo goda [What and where is imported to Kazakhstan on the eve of the New Year] (2019). Available at: https://kursiv.kz/ news/obschestvo/ 2019-12/ chto-i-otkuda-zavozyat- v- kazakhstan- v -preddverii- novogo- goda (date of access: 14.10.2021). [in Russian].

[8] Limony na ves zolota: vsego za mesyats tsena na eti poleznyye plody tsitrusovykh vyrosla yeshcho na $48 \%$ [Lemons are worth their weight in gold: in just a month, the price of these healthy citrus fruits increased by another 48\%] (2020). Available at: https://www.energy-prom. $\mathrm{kz} / \mathrm{ru} / \mathrm{a} /$ monitoring/ (date of access: 12.10.2021). [in Russian].

[9] Ekzoticheskiye dlya Kazakhstana limony vyrashchivayut $v$ rayonakh YUKO [Lemons exotic for Kazakhstan are grown in the regions of South Kazakhstan region] (2018). Available at: https://otyrar.kz/2018/01/ekzoticheskie-dlyakazaxstana-limony-vyrashhivayut-v-rajonaxyuko/ (date of access: 12.10.2021). [in Russian].

[10] Tazhibayeva, R.M. (2021). Gosudarstvennaya podderzhka agrarnogo sektora Kazakhstana [Public support for agricultural sector of Kazakhstan] Problemy agrorynka - Problems of agrimarket, 1, 44-49. [in Russian].

\section{Информация об авторах:}

Калиакпарова Гульнар Шаймардановна - основной автор; доктор Ph.D; заведующая кафедрой «Экономика и бизнес»; академия «Кайнар»; 050013 ул. Сатпаева, 7а, г.Алматы, Казахстан; e-mail: GK_2003@rambler.ru; https:// orcid.org/0000-0002-1859-9774

Гриднева Елена Евгеньевна; кандидат экономических наук, доцент; профессор кафедры «Экономика и бизнес»; академия «Кайнар»; 050013 ул. Сатпаева, 7а, г.Алматы, Казахстан; е-таil: elengred@ail.ru; https://orcid.org/0000-0002-3279-2036

\section{Авторлар туралы ақпарат:}

Калиакпарова Гульнар Шаймардановна - негізгі автор; Ph.D докторы; «Экономика және бизнес» кафедрасының меңгерушісі; «Кайнар» академиясы; 050013 Сәтбаев көш., 7а, Алматы қ., Қазақстан; e-mail: GK_2003@rambler.ru; https:// orcid.org/0000-0002-1859-9774

Гриднева Елена Евгеньевна; экономика ғылымдарының кандидаты, доцент; «Экономика және бизнес» кафедрасы профессоры; «Қайнар» академиясы; 050013 Сәтбаев көш., 7а, Алматы қ., Қазақстан; e-mail: elengred@mail.ru; https://orcid.org/0000-0002-3279-2036

\section{Information about authors:}

Kaliakparova Gulnar Shaimardanovna - The main author; Ph.D; Head of the Department of Economics and Business; "Kainar» Academy; 050013 Satpayev str., 7a, Almaty, Kazakhstan; e-mail: GK_2003@rambler.ru; https:// orcid.org/0000-0002-1859-9774

Gridneva Yelena Evgenevna; Candidate of Economic Sciences, Associate Professor; Professor of the Department of Economics and Business; "Kainar» Academy; 050013 Satpayev str., 7a, Almaty, Kazakhstan; e-mail: elengred@mail.ru; https://orcid.org/0000-0002-3279-2036 